P16

From Geochemistry to Stratigraphy: Unraveling the History of Three Oil Machines in Kuwait

R. Andriany* (Kuwait Oil Company), A. Al-Khamiss (Kuwait Oil Company) \& G. Al-Sahlan (Kuwait Oil Company)

\author{
For abstract, PTO \\ No full paper available
}




\title{
15101 From geochemistry to stratigraphy: Unraveling the history of three oil machines in Kuwait
}

\author{
Rita Andriany (Kuwait Oil Company <RAndriany@kockw.com>), \\ Awatif Al-Khamiss (Kuwait Oil Company) and Ghaida Al-Sahlan (Kuwait Oil Company)
}

The application of biological markers (biomarkers) as geochemical fossils for exploration, development, and production purposes is growing rapidly. Their ability to retain the chemical structures during geological processes has been utilized to differentiate among three main source-rock intervals from Late Jurassic to Early Cretaceous. Two source-rock intervals, the Oxfordian Najmah and Berriasian Makhul formations, have been recognized as two giant oil machines. The presence of a fine-grained interval in the Hith Formation opens a new target for exploration.

A number of selected compounds of biomarkers and carbon-isotope ratios can separate these three source rocks (fine-grained intervals) into their genetic relationship: Makhul (cluster-1), Najmah (cluster-3), Gotnia and Hith (cluster-4). The evidence of similarity (genetic relationship) between oil stains and core within the Hith Formation is the crucial clue for exploration. It indicates that the finegrained interval within the Hith Formation is a new potential charge. However, due to the limited evidence that is based on just one sample more data should be examined to improve the reliability of the interpretation.

Oxygen levels change with sea-level fluctuations and glaciations, and an increase of the oxygen intensity in the water column will decrease the amount of preserved organic matter. The history of oxidation and reduction during sedimentation processes can be determined by comparing the pristane / phytane $(\mathrm{Pr} /$ $\mathrm{Ph}$ ) ratios over selected parameters including the pristane/n-C17, phytane/n-18, gammacerane index, and canonical variable. A general decrease in $\mathrm{Pr} / \mathrm{n}-\mathrm{C} 17$, and the absence of gammacerane accompanied by high $\mathrm{Ph} / \mathrm{n}-\mathrm{C} 18$ (>0.3), porphyrin and sulfur content, within the Najmah source rock, indicates the deposition of carbonates in an anoxic marine environment. The Najmah source rock contains more total organic matter (TOC weight \%) than the Makhul source rock. In summary, geochemical fossils in fine-grained intervals are not only capable of unraveling genetic relationships (oil-oil to source correlation), but also can be utilized as stratigraphic markers because they retain chemical structures during geological processes. 